\title{
Analysis on the Whitewashing Motivation of Financial Statement of Listed Real Estate Companies in China
}

\author{
Wei Weng \\ Yunnan Normal University \\ Kunming, Yunnan, China \\ Email:vemal@163.com
}

\author{
Xiaoyuan Zhu, Ningbang Wang and Bo Peng* \\ Yunnan Normal University \\ Kunming, Yunnan, China
}

\begin{abstract}
Starting from the whitewashing situation of the financial statements of real estate enterprises with whitewash motivation, case analysis is carried on based on the previous theoretical research. Through the study of the research on the whitewash motivations and methods of real estate enterprises, and combining the characteristics and situations of real estate to analysis, some prevention methods would be put forward, which is of certain significance for the effectiveness of economic management and the stability of the real estate company management.
\end{abstract}

Keywords: listed companies; real estate; financial statements whitewashing; motivation

I. WHITEWASH SITUATION OF THE FINANCIAL STATEMENT OF LISTED REAL ESTATE COMPANIES

Financial Security Assessment Report on the Non-financial Listed Companies in China in 2017 selected 2696 non-financial listed companies as the data samples, using Themis's Pure Quantitative Outliers Credit Rating Technology to analyze the total index of their financial security. The situation of third industry is as follows:

TABLE 1 THE FINANCIAL SECURITY INDEX OF THE THIRD INDUSTRY FROM 2013 TO 2017

\begin{tabular}{|l|l|l|l|l|l|}
\hline \multicolumn{1}{|c|}{ Year } & \multicolumn{1}{c|}{2013} & \multicolumn{1}{c|}{2014} & \multicolumn{1}{c|}{2015} & \multicolumn{1}{c|}{2016} & \multicolumn{1}{c|}{2017} \\
\hline Communicatio & 5025.9 & 4896.6 & 5016.9 & 5200.0 & 5674.1 \\
n & 7 & 6 & 5 & 0 & 4 \\
\hline Traffic and & 5496.9 & 5065.3 & 5237.3 & 5645.7 & 5606.9 \\
Transportation & 2 & 3 & 3 & 8 & 0 \\
\hline Computer & 6159.7 & 5924.1 & 5716.6 & 5457.8 & 5206.8 \\
& 8 & 7 & 7 & 9 & 5 \\
\hline Commercial & 5253.7 & 5480.5 & 5339.7 & 5139.3 & 4924.4 \\
trade & 6 & 2 & 4 & 3 & 2 \\
\hline \multirow{2}{*}{ Leisure Service } & 5290.6 & 5433.3 & 4660.0 & 4893.7 & 4793.5 \\
& 2 & 3 & 0 & 5 & 5 \\
\hline \multirow{2}{*}{ Real Estate } & 2152.8 & 2380.0 & 2097.0 & 2157.2 & 1885.5 \\
& 9 & 0 & 4 & 5 & 0 \\
\hline
\end{tabular}

According to the above table, it is explicit that the real estate industry has a low financial security index between 2013 and 2017. In the first half of 2017, 98 companies get involved in the financial statements whitewash, accounting for 70.01 percent of the 138 samples selected, and more than one half of the real estate companies have the suspicion on financial statements whitewash. Due to other industries of FSI index is far higher than that of the real estate industry, for its financial statements whitewash with the most serious suspicion and the lowest security industry, which lower the total financial security index of the tertiary industry, affected by the serious social and economic development.

TABLE 2 LISTED COMPANIES WITH SUBSTANTIAL GROWTH IN FINANCIAL SECURITY IN 2017

\begin{tabular}{|l|l|l|l|l|}
\hline Ranking & $\begin{array}{l}\text { Types of } \\
\text { industry }\end{array}$ & $\begin{array}{l}\text { Number of } \\
\text { Company } \\
\text { whose } \\
\text { score going } \\
\text { up }\end{array}$ & $\begin{array}{l}\text { Total } \\
\text { Number of } \\
\text { the } \\
\text { Companies } \\
\text { of industry } \\
\text { involved }\end{array}$ & $\begin{array}{l}\text { Ratio of } \\
\text { company } \\
\text { whose } \\
\text { score } \\
\text { going up }\end{array}$ \\
\hline 1 & Real Estate & 39 & 138 & $28.26 \%$ \\
\hline 2 & $\begin{array}{l}\text { The } \\
\text { integrated }\end{array}$ & 9 & 39 & $23.08 \%$ \\
\hline 3 & Electron & 28 & 158 & $17.72 \%$ \\
\hline 4 & $\begin{array}{l}\text { Mining } \\
\text { and } \\
\text { Quarrying }\end{array}$ & 9 & 62 & $14.52 \%$ \\
\hline 5 & $\begin{array}{l}\text { Iron and } \\
\text { Steel }\end{array}$ & 4 & 32 & $12.50 \%$ \\
\hline 6 & $\begin{array}{l}\text { Building } \\
\text { Materials }\end{array}$ & 8 & 67 & $11.94 \%$ \\
\hline
\end{tabular}

As can be seen from the above diagram, the largest increase has been gotten in financial security of real estate companies. The index of financial security in real estate industry is less satisfactory in 2017 , but such situation that has been being improved which needs us to work on.

\section{ANALYSIS ON THE WHITEWASH MOTIVATION OF FINANCIAL STATEMENTS OF LISTED COMPANY IN REAL ESTATE}

\section{A. Avoidance of Being ST or Delisted}

Real estate needs large financial support in the whole process of production and management for its large occupation of funds but long production cycle. ST, English abbreviation of the Special Treatment, refers to a situation that a company would be treated specially for its deficit for 2 years and ST would be added before the original name of the stock, and a continuing loss at company lead to the risk of being delisted and stop of the stock exchange after a disqualification, which is grim for listed real estate enterprise by reason of suffering from the an awful lot to lose and above all being lose the chance of social fund-raising. It is difficult to survive from bank loan only for real estate company, which means that the company has the tendency easily of making a decision of whitewashing the statements after 2-year continuing loss.

B. Motivation of Tax Evasion and Avoidance 
TABLE 3 INCOME TAX TABLE OF INDUSTRIES BETWEEN 2012 AND 2016

\begin{tabular}{|l|l|l|l|l|l|l|}
\hline Year & 2012 & 2013 & 2014 & 2015 & 2016 & Average tax \\
\hline Real estate & $10.64 \%$ & $9.59 \%$ & $9.61 \%$ & $9.60 \%$ & $9.26 \%$ & $9.74 \%$ \\
\hline The integrated & $6.75 \%$ & $5.89 \%$ & $6.56 \%$ & $7.10 \%$ & $7.15 \%$ & $6.69 \%$ \\
\hline Accommodation and catering & $6.73 \%$ & $6.67 \%$ & $6.56 \%$ & $6.33 \%$ & $6.42 \%$ & $6.54 \%$ \\
\hline Traffic and Transportation & $7.46 \%$ & $6.75 \%$ & $5.70 \%$ & $5.42 \%$ & $5.07 \%$ & $6.08 \%$ \\
\hline Mining sport and & $5.80 \%$ & $5.62 \%$ & $5.79 \%$ & $4.63 \%$ & $5.15 \%$ & $5.40 \%$ \\
\hline $\begin{array}{l}\text { Culture, } \\
\text { entertainment }\end{array}$ & $4.55 \%$ & $4.27 \%$ & $4.16 \%$ & $4.34 \%$ & $3.94 \%$ & $4.25 \%$ \\
\hline Construction industry & $3.81 \%$ & $2.83 \%$ & $3.34 \%$ & $3.84 \%$ & $4.38 \%$ & $3.64 \%$ \\
\hline Wholesale and retail & $3.60 \%$ & $2.52 \%$ & $2.30 \%$ & $3.57 \%$ & $2.84 \%$ & $2.97 \%$ \\
\hline Production & $2.57 \%$ & $2.42 \%$ & $2.40 \%$ & $2.31 \%$ & $2.41 \%$ & $2.42 \%$ \\
\hline $\begin{array}{l}\text { Agriculture, forestry, animal } \\
\text { husbandry and fishery }\end{array}$ & $0.77 \%$ & $1.08 \%$ & $1.07 \%$ & $1.10 \%$ & $0.96 \%$ & $1.00 \%$ \\
\hline
\end{tabular}

According to the relevant data of Sohu Finance, tax situation of 10 industries have been selected in table 3 to make a comparison with real estate industry. For average tax, the tax ratio $9.74 \%$ in real estate industry is the highest and more three times higher than construction industry. Property tax, land value-added tax, deed tax, the land use tax and so on are obligatory pay duty in the process of production and business operation in real estate company, after May 1, 2016, the real estate industry achieves replacing business tax with value-added tax, relative to other industries, the real estate company has been facing the double payment standard of value added tax and business tax, the high tax could be explicit from the result that about $15 \%$ in fiscal revenue is from property taxes.

\section{Financing Motivation}

In 2016, a share of 136 listed real estate grows year on year liabilities by $25.93 \%$, and total liabilities exceed 4.92 trillion yuan, as shown blow.

\section{TABLE 4 LISTED REAL ESTATE INTERPRISE WITH THE ASSET-LIABILITY RATIO ABOVE 80\%}

\begin{tabular}{|c|c|c|c|c|c|}
\hline Ranking & Name & Liquidity ratio & Quick ratio & Cash ratio & Assert-liability ratio \\
\hline 1 & ST the Pearl River & $0.63 \%$ & $0.30 \%$ & $6.99 \%$ & $116.88 \%$ \\
\hline 2 & Gentle Town & $1.14 \%$ & $0.14 \%$ & $7.25 \%$ & $94.60 \%$ \\
\hline 3 & Lushang Property co., ltd & $1.39 \%$ & $0.34 \%$ & $9.97 \%$ & $94.00 \%$ \\
\hline 4 & Metro Land CorporationLtd. & $2.01 \%$ & $0.39 \%$ & $24.19 \%$ & $90.68 \%$ \\
\hline 5 & CIITY & $1.91 \%$ & $0.57 \%$ & $29.50 \%$ & $90.39 \%$ \\
\hline 6 & $\begin{array}{l}\text { Yunnan } \\
\text { Development Company Limited }\end{array}$ & $1.97 \%$ & $0.35 \%$ & $20.49 \%$ & $89.67 \%$ \\
\hline 7 & Greenland Holdings Group & $1.64 \%$ & $0.49 \%$ & $17.23 \%$ & $88.80 \%$ \\
\hline 8 & ST China-interprise & $1.52 \%$ & $0.44 \%$ & $35.67 \%$ & $87.55 \%$ \\
\hline 9 & TANDE & $2.35 \%$ & $0.52 \%$ & $34.93 \%$ & $87.32 \%$ \\
\hline 10 & Future Land Holdings Group & $1.24 \%$ & $0.57 \%$ & $25.44 \%$ & $85.77 \%$ \\
\hline
\end{tabular}

Among the 136 listed real estate companies, the average asset-liability ratio is up to $77.26 \%$. In addition to the companies listed above, the asset-liability ratio of industry leaders such as Vanke is over $80 \%$. Asset-liability ratio is too high, debt-repaying ability is weak, investors or creditors would consider that investing a company with a bad economic situation runs a high risk, which results in people no longer buying its bonds or loans for its high assert-liability ratio and weak overall debt repayment ability to influence financing capability. Therefore, real estate companies would have the incentive to whitewash their statements so as to adjust their profits to establish a good image.

In addition to the high asset-liability ratio, real estate companies have the characteristic of high percentage of fund. As for the high assert-liability ratio, long-term loans, as a source of funds for a long time, would not only increase the financial risk of the company, but under the condition of the loan restrictions, it is hard to meet the needs of the large amounts of money so that refinancing becomes the best choice at this moment, but in the last three full fiscal year, it harshly demands an average annual return on equity is of over $10 \%$. Companies would create incentives to gloss over statements, creating the illusion of perennial profitability.

\section{Long Production Cycle}

Many projects of real estate companies have to be maintained for a long period of time, and the production cycle of the products used for sales is long, and sales process of the final product generally needs to be divided into sales and advance sale. The confirmation of sales revenue of real estate company generally means that the product is completed and the acceptance is qualified -- the buyer and the seller sign the legal sales contract -- the relevant proof of purchasing a house -- the delivery and use 
of the premise. In other words, for real estate industry the reality of profit and loss could not be calculated until the delivery and use of purchasers and sellers are included in sales revenue whose confirmation provides a good condition for its cost.

For instance, various methods are artificially used to adjust sales revenue in order to inflate or reduce the net profit.

Common counterfeiting methods to inflate(reduce)sales revenue in real estate industry

\begin{tabular}{|c|c|}
\hline Inflating sales revenue & Reducing sales revenue \\
\hline $\begin{array}{l}\text { Confirmation in advance the } \\
\text { following types of sales revenue } \\
\text { 1. Confirmation of revenue under } \\
\text { the existence of great uncertainty } \\
2 \text {. Improper usage of the } \\
\text { percentage of completion method: The } \\
\text { relevant regulations shall be confirmed } \\
\text { in accordance with the project } \\
\text { schedule, and the sales revenue shall } \\
\text { be confirmed by more confirmation of } \\
\text { the progress of the project. } \\
\text { 3. Issue sales invoices in advance } \\
\text { to beautify the report. }\end{array}$ & $\begin{array}{l}\text { 1. The project settlement } \\
\text { is postponed artificially and } \\
\text { pre-selling house payment is } \\
\text { stayed in the account to } \\
\text { delay the confirming time of } \\
\text { sales. } \\
\text { 2. Delay the time of } \\
\text { issuing the special invoice } \\
\text { for sales of real estate to } \\
\text { adjust the sales revenue. }\end{array}$ \\
\hline
\end{tabular}

Figure 1 A chart of falsification methods for sales revenue of housing enterprises

\section{CONCLUSION}

The financial security index of real estate enterprises could be increased with a tougher degree of relevant legal responsibilities. When the fraud cost is much higher than the benefits it could bring, the occurrence of the financial statement whitewash would be reduced. During the process: firstly, in the relevant provisions of the law, there should be a clear determination of the responsibilities of the illegal subject and the illegal subject. Secondly, criminal punishment, generally used for CPA, is not very severe, and its limitations need to be considered while increasing the punishment. Thirdly, it is necessary to improve the existing judicial system to make the lawbreakers hold the same intensity of punishment with the degree of illegal items, for instance, once the illegal behavior of listed companies has been found in financial aspect, the penalties of suspension and delisting should be taken directly. The degree of punishment could only be harsher, which could make effects correspondingly.

\section{REFERENCES}

[1] Ingram and Howard.An Empirical Analysis of the Relation Between the Board of Director Composition and Financial Statement Fraud[J].Journal of Accounting and Econnomics, Vol33,1999,5-23.

[2] Howard.R Davia.A decition aid for assessing the likelihood of fraudulent financial reporting 2000 (01) [R].New
[Now York:ACFE,2004,21-27.

[3] Yan Xiang-ju. Analysis on the sales revenue fraud and audit strategy of real estate enterprises [J]. Friends of accounting, 2013, 75-76.

[4] Liu Dong-sheng, Li Qing. Whitewashing behavior and prevention analysis of financial statements of listed companies [J]. Academic BBS, 2014, 78-84.
[5] Ying Mengli, Yang Jie, Lin Sihan. Case analysis and enlightenment of financial fraud in hailianxun [J]. Financial and accounting communications, 2016, 18-22.

[6] Ding Hao, Liu Ling. Whitewash identification of financial statements of listed companies [J]. Research on technology, economy and management, 2011, 13-17.

[7] Chen Feng-xia, Wang Rrong. Research on the safety of real estate industry $[\mathrm{J}]$. Financial and accounting communications,2017, 79-81. 